\title{
4-Sulphobenzoate 3,4-dioxygenase
}

\section{Purification and properties of a desulphonative two-component enzyme system from Comamonas testosteroni T-2}

\author{
Hans H. LOCHER, Thomas LEISINGER and Alasdair M. COOK* \\ Microbiology Institute, Swiss Federal Institute of Technology, CH-8092 Zürich, Switzerland
}

\begin{abstract}
Cell-free extracts of Comamonas testosteroni T-2 grown in toluene-p-sulphonate/salts medium catalyse the conversion of $p$-sulphobenzoate (PSB) into protocatechuate and sulphite by an NADH-requiring and $\mathrm{Fe}^{2+}$-activated dioxygenase. Anionexchange chromatography of extracts yielded red (A) and yellow (B) protein fractions, both of which were necessary for dioxygenative activity. Further purification of each fraction by hydrophobic interaction chromatography and gel filtration led to two homogeneous protein components (A and B), which together converted 1 mol each of PSB, $\mathrm{O}_{2}$ and NADH into $1 \mathrm{~mol}$ each of protocatechuate, sulphite and, presumably, $\mathrm{NAD}^{+}$. The system was named 4-sulphobenzoate 3,4dioxygenase (PSB dioxygenase system). Monomeric component $\mathrm{B}\left(M_{\mathrm{r}} 36000\right)$ was determined to be a reductase that contained $1 \mathrm{~mol}$ of FMN and about $2 \mathrm{~mol}$ each of iron and inorganic sulphur per mol. This component transferred electrons from NADH to the oxygenase component (A) or to, e.g., cytochrome $c$. Homodimeric component A (subunit $\left.M_{\mathrm{r}} 50000\right)$ of the PSB dioxygenase system contained one [2Fe-2S] centre per subunit and its u.v.-visible-absorption spectrum corresponded to a Rieske-type iron-sulphur centre. The requirement for activation by iron was interpreted as partial loss of mononuclear iron during purification of component A. Component A could be reduced by dithionite or by NADH plus catalytic amounts of component B. The PSB dioxygenase system displayed a narrow substrate range: none of 18 sulphonated or non-sulphonated analogues of PSB showed significant substrate-dependent $\mathrm{O}_{2}$ uptake. The physical properties of the PSB dioxygenase system resemble those of other bacterial multi-component dioxygenases, especially phthalate dioxygenase. However, it differs from most characterized systems in its overall reaction: the product is a vicinal diphenol, and not a dihydrodiol.
\end{abstract}

\section{INTRODUCTION}

Sulphonated aromatic compounds are essentially xenobiotics whose biodegradation has been studied for about 40 years (Cain, 1981 ; Thurnheer et al., 1986), but whose desulphonation in vitro has only recently become available (Thurnheer et al., 1986, 1990; Locher et al., 1989). Many desulphonation mechanisms have been reviewed (Swisher, 1987), but the only reactions with published experimental support involve dioxygenases (Cain \& Farr, 1968; Brilon et al., 1981) or mono-oxygenases (Zürrer et al., 1987) acting on the carbon atom carrying the sulphonate moiety. Quantitative and qualitative proofs of the activity of dioxygenases that involve desulphonation are now available (Locher et al., 1989; Thurnheer et al., 1990).

Comamonas testosteroni T-2 degrades toluene-p-sulphonate (TS) by mono-oxygenation of the methyl side chain to the corresponding alcohol, which is oxidized in two $\mathrm{NAD}^{+}$-coupled reactions to $p$-sulphobenzoate (PSB). PSB is subject to desulphonative dioxygenation and the first known product is protocatechuate, which is subject to meta ring cleavage (Locher et al., 1989) (Scheme 1).

We now report the first purification and some properties of a desulphonative two-component dioxygenase, which we term the 4-sulphobenzoate 3,4-dioxygenase system (PSBDOS).

\section{EXPERIMENTAL}

\section{Materials}

Protamine sulphate, $\left(\mathrm{NH}_{4}\right)_{2} \mathrm{SO}_{4}, \mathrm{Na}_{2} \mathrm{SO}_{4}$, dithiothreitol, dichlorophenol-indophenol and terephthalate were purchased from Fluka, Buchs, Switzerland. NADH, NADPH, NAD ${ }^{+}$, FAD, FMN, riboflavin and cytochrome $c$ were obtained from Boehringer, Mannheim, Germany. Ferricyanide, ferredoxin from Spirulina platensis and Iron AAS Standard Solution were supplied by Sigma Chemical Co., St. Louis, MO, U.S.A. Prepacked columns for f.p.l.c. were used; G3000 SW (21.5 mm $\times 300 \mathrm{~mm})$ and G2000 SW $(7.5 \mathrm{~mm} \times 600 \mathrm{~mm})$ were from Toyo Soda, Tokyo, Japan, and Mono Q $(16 \mathrm{~mm} \times 100 \mathrm{~mm})$, phenyl-Superose $(5 \mathrm{~mm} \times 50 \mathrm{~mm})$, Superose $12(10 \mathrm{~mm} \times 300 \mathrm{~mm})$ and Pro RPC $(15 \mu \mathrm{m}$ particle size; $10 \mathrm{~mm} \times 100 \mathrm{~mm})$ were from Pharmacia, Uppsala, Sweden, which also provided Blue Dextran 2000, native standard proteins and PD-10 columns of Sephadex G-25. Centriprep membrane filtration units were from Amicon, Danvers, MA, U.S.A. Reagents and standards for SDS/PAGE were from Bio-Rad Laboratories, Richmond, CA, U.S.A. Immobilon [poly(vinylidene difluoride)] membranes were from Millipore, Bedford, MA, U.S.A. The 4-sulphono derivatives of phenylacetate, 3-phenylpropionate and 4-phenylbutyrate were a gift from Dr. A. Marcomini. The sources of other chemicals are reported elsewhere (Locher et al., 1989; Scholtz et al., 1987). Chemicals used were of the best quality available commercially.
Analytical methods
H.p.l.c. This was done with reverse-phase columns on LKB apparatus described elsewhere (Locher et al., 1989). The mobile phases consisted of (i) $50 \mathrm{~mm}$-potassium phosphate buffer, pH 2.2, and appropriate concentrations of methanol $[15 \%(\mathrm{v} / \mathrm{v})$ for PSB, $30 \%(\mathrm{v} / \mathrm{v})$ for flavins, $50 \%(\mathrm{v} / \mathrm{v})$ for terephthalate] (Locher et al., 1989) or (ii) $100 \mathrm{~mm}$-ammonium acetate buffer, 


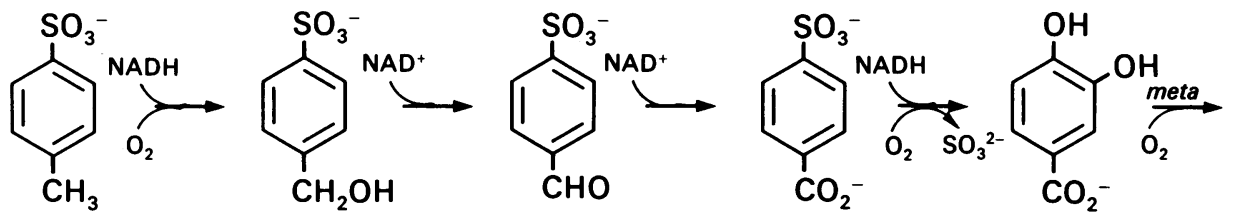

Scheme 1. Degradative pathway of TS in C. testosteroni T-2

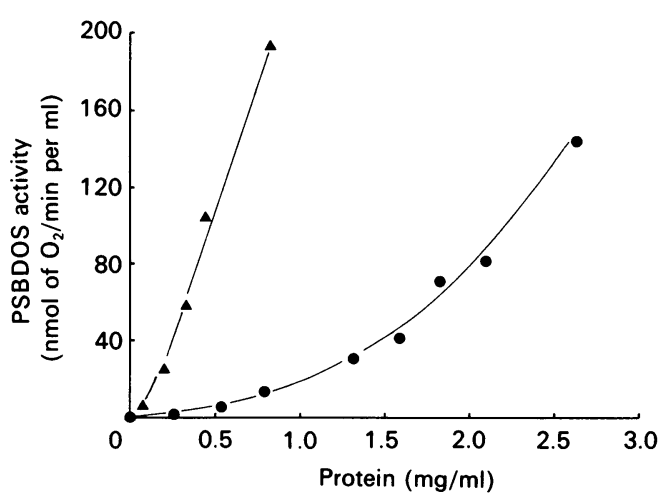

Fig. 1. Dependence of PSBDOS activity on protein concentration

The activity of PSBDOS was determined as $\mathrm{O}_{2}$ uptake in crude extract $(O)$ or in crude extract to which $70 \mu \mathrm{g}$ of purified component $\mathrm{B}$ was added (A).

pH 4.8, and $30 \%$ (v/v) methanol (for flavins) (Buder \& Fuchs, 1989).

Determination of iron and inorganic sulphur. The iron content of component A or B was determined in duplicate in samples from different purifications by atomic absorption spectroscopy with a Video 12 apparatus (Nanolab, Schlieren, Switzerland). Proteins were desalted on PD-10 columns and their iron contents compared with standards prepared in acid-washed glassware with iron-free water. Buffer samples without protein were treated the same way and were used for background corrections.

Inorganic sulphur was extracted from proteins in duplicate in samples from different purifications by zinc acetate treatment and determined as the formation of Methylene Blue (Beinert, 1983). Ferredoxin from $S$. platensis was used as a positive control.

Determination of flavin content. Flavin cofactors were extracted from protein either by boiling for $5 \mathrm{~min}$ or by stirring for $3 \mathrm{~min}$ in $5 \%(\mathrm{w} / \mathrm{v})$ trichloroacetic acid. The precipitated protein was removed by centrifugation, and the concentration of FMN, FAD or riboflavin in the yellow supernatant fluid was determined by h.p.l.c. with two different mobile phases and with u.v. detection at $260 \mathrm{~nm}$. Both methods allowed a clear separation of FMN, FAD and riboflavin. The FMN concentration in the supernatant fluid from acid-precipitated protein was also determined spectrophotometrically at $450 \mathrm{~nm}\left(\epsilon_{450}=12200 \mathrm{M}^{-1} \cdot \mathrm{cm}^{-1}\right.$; Batie et al., 1987). The identity of the flavin from component $B$ was confirmed by co-chromatography with authentic material and by its u.v.-absorption spectrum in a diode array detector.

Determination of $\boldsymbol{N}$-terminal amino acid sequences. $N$-Terminal amino acid sequences were determined both with purified and desalted protein samples and with protein bands blotted from SDS/PAGE on to Immobilon membranes [according to Applied Biosystems (Foster City, CA, U.S.A.) User Bulletin no. 25]. The peptides were subjected to Edman degradation in a $470 \mathrm{~A}$ gas- phase sequencer, and phenylthiohydantoin derivatives were identified on-line with a 120A phenylthiohydantoin analyser (Applied Biosystems). Samples were desalted by reverse-phase chromatography on an RPC column at a flow rate of $1.5 \mathrm{ml} / \mathrm{min}$. The eluent consisted of aq. $0.1 \%(\mathrm{v} / \mathrm{v})$ trifluoroacetic acid, and proteins were eluted by a linear gradient of acetonitrile [0-100\% $(\mathrm{v} / \mathrm{v})$ in $30 \mathrm{~min}]$.

Determinations of amino acid composition. Purified and desalted protein samples were hydrolysed in the gas phase in $6 \mathrm{M}-\mathrm{HCl}$ at $160^{\circ} \mathrm{C}$ for $1 \mathrm{~h}$. Amino acid phenylthiohydantoin derivatives were prepared with a $420 \mathrm{~A}$ synthesizer and analysed on a $120 \mathrm{~A}$ separation system (Applied Biosystems). The values obtained were corrected where necessary for losses during hydrolysis.

Photometric determinations and absorption spectra. These were obtained in an Uvikon 820 spectrophotometer (Kontron, Zürich, Switzerland).

Determination of protein concentration. Protein concentrations were measured routinely by the method of Bradford (1976). Samples used for iron, inorganic sulphur and flavin analyses were also assayed by the method of Lowry et al. (1951). BSA served as a standard in both methods.

Electrophoresis. Purification of components A and B from PSBDOS was monitored by SDS/PAGE (Laemmli, 1970). Slab gels $(7 \mathrm{~cm} \times 8 \mathrm{~cm} \times 0.75 \mathrm{~mm})$ containing $12 \% \quad(w / v)$ polyacrylamide in the separating gel and $4 \%$ in the stacking gel were stained routinely in $0.2 \%$ Coomassie Brilliant Blue R250 dissolved in aq. $50 \%(\mathrm{v} / \mathrm{v})$ methanol $/ 10 \%(\mathrm{v} / \mathrm{v})$ acetic acid for $30 \mathrm{~min}$ and then destained in aq. $10 \%(\mathrm{v} / \mathrm{v})$ methanol $/ 10 \%$ (v/v) acetic acid. Gels were also subjected to silver staining (Merril et al., 1983).

Determination of $M_{\mathrm{r}} \cdot M_{\mathrm{r}}$ values of proteins under denaturing conditions were estimated by SDS/PAGE. Phosphorylase $b$ $\left(M_{\mathrm{r}} 97400\right)$, BSA $\left(M_{\mathrm{r}} 66200\right)$, ovalbumin $\left(M_{\mathrm{r}} 45000\right)$, carbonic anhydrase $\left(M_{\mathrm{r}} 31000\right)$, trypsin inhibitor $\left(M_{\mathrm{r}} 21500\right)$ and lysozyme $\left(M_{\mathrm{r}} 14400\right)$ were used as standards. $M_{\mathrm{r}}$ values for native proteins were determined by gel filtration through the Superose column and the G2000 column at a flow rate of $0.6 \mathrm{ml} / \mathrm{min}$. The eluent was $50 \mathrm{~mm}$-potassium phosphate buffer, pH 6.8, containing $150 \mathrm{~mm}-\mathrm{Na}_{2} \mathrm{SO}_{4}$, and the calibration proteins were ferritin $\left(M_{\mathrm{r}} 440000\right)$, catalase $\left(M_{\mathrm{r}} 232000\right)$, fructosebisphosphate aldolase $\left(M_{\mathrm{r}} 158000\right)$, BSA $\left(M_{\mathrm{r}} 67000\right)$, ovalbumin $\left(M_{\mathrm{r}}\right.$ 43000), chymotrypsinogen $\left(M_{\mathrm{r}} 25000\right)$ and RNAase A $\left(M_{\mathrm{r}}\right.$ 13700). The void volume of the column was estimated with Blue Dextran 2000.

\section{Enzyme assays}

Assays for oxygenases. The activity of PSB dioxygenase was assayed routinely as $\mathrm{O}_{2}$ uptake. A Clarke-type oxygen electrode with a thermostatically controlled $\left(30^{\circ} \mathrm{C}\right) 1 \mathrm{ml}$ vessel was used (Rank Bros., Bottisham, Cambs., U.K.). The reaction was optimized for buffer and $\mathrm{pH}$, and for the concentrations of 
buffer, NADH, $\mathrm{Fe}^{2+}$ and PSB; it contained (in $0.5 \mathrm{ml}$ ) $10 \mu \mathrm{mol}$ of potassium phosphate buffer, $\mathrm{pH} 6.8,200 \mathrm{nmol}$ of $\mathrm{NADH}$, $40 \mathrm{nmol}$ of $\mathrm{FeSO}_{4}$ and $0.8 \mathrm{mg}$ of protein, and the reaction was started by the addition of $500 \mathrm{nmol}$ of PSB. The response of $\mathrm{O}_{2}$ uptake as a function of protein concentration was non-linear (Fig. 1), so the protein concentration was set arbitrarily at $0.8 \mathrm{mg} /$ test to allow comparisons to be made. When real specific activities of component $A$ were required (e.g. Table 1), partially purified reductase B [70 $\mu \mathrm{g}$ of protein from step $3 \mathrm{~b}$ (see below)] was included, and a nearly linear response of $\mathrm{O}_{2}$-uptake rate as a function of component A was obtained (Fig. 1). In calculations, the endogenous rate of $\mathrm{O}_{2}$ consumption, recorded in the absence of substrate, was subtracted from the gross reaction rate. Further, crude extracts contained protocatechuate 4,5-dioxygenase at 10-fold higher activity than the desulphonation (Locher et al., 1989), so the $\mathrm{O}_{2}$-uptake rates were halved to obtain net activities of PSB dioxygenase. Results are expressed routinely as katals.

Apparent $K_{\mathrm{m}}$ values for the purified oxygenase were derived from progress curves of reactions in the oxygen electrode at PSB concentrations between 0 and $50 \mu \mathrm{M}$ by the method of Halwachs (1978): $5.5 \mu \mathrm{M}$-component $\mathrm{B}$ was used and the $\mathrm{O}_{2}$ concentration was between 0.2 and $0.1 \mathrm{mM}$.

The reaction of the PSB dioxygenase was confirmed with colorimetric measurements of sulphite production (Thurnheer et al., 1986) and determinations of PSB disappearance and protocatechuate formation by h.p.l.c. Terephthalate transformation was also monitored by h.p.l.c.

Protocatechuate 4,5-dioxygenase activity was assayed as $\mathrm{O}_{2}$ uptake at $30^{\circ} \mathrm{C}$. Reaction mixtùres contained (in $0.5 \mathrm{ml}$ ) $10 \mu \mathrm{mol}$ of potassium phosphate buffer, $\mathrm{pH} 6.8,40 \mathrm{nmol}$ of $\mathrm{FeSO}_{4}$ and $0.5 \mathrm{mg}$ of protein, and the reaction was started by the addition of $1 \mu \mathrm{mol}$ of protocatechuate.

TS mono-oxygenase activity was assayed as $\mathrm{O}_{2}$ uptake at $30^{\circ} \mathrm{C}$. The reaction mixture contained (in $0.5 \mathrm{ml}$ ) $10 \mu \mathrm{mol}$ of potassium phosphate buffer, pH 6.8, $200 \mathrm{nmol}$ of NADH, $40 \mathrm{nmol}$ of $\mathrm{FeSO}_{4}$ and $0.5 \mathrm{mg}$ of protein, and the reaction was started by the addition of $500 \mathrm{nmol}$ of TS. Assays of partially purified mono-oxygenase free of reductase were augmented with reductase $B$ as described above for PSBDOS.

Reductases. Reductase B of PSBDOS (and reductase C) was routinely assayed at $25^{\circ} \mathrm{C}$ as cytochrome $c$ reduction. The reaction mixture contained (in $1.0 \mathrm{ml}$ ) $19 \mu \mathrm{mol}$ of potassium phosphate buffer, $\mathrm{pH} 6.8,15 \mathrm{nmol}$ of cytochrome $c$ and $0.2-20 \mu \mathrm{g}$ of protein, and the reaction was started by the addition of $100 \mathrm{nmol}$ of NADH. The increase in absorbance at $550 \mathrm{~nm}$ was monitored; $\epsilon_{550}$ was taken to be $21000 \mathrm{M}^{-1} \cdot \mathrm{cm}^{-1}$ (Ensley et al., 1982). PSBDOS reductase $B$ was also measured as the reduction of ferricyanide under similar conditions, with $1 \mu \mathrm{mol}$ of ferricyanide instead of cytochrome $c$. The decrease in absorbance at $420 \mathrm{~nm}$ was monitored and $\epsilon_{420}$ was taken to be $1020 \mathrm{M}^{-1} \cdot \mathrm{cm}^{-1}$ (Yamaguchi \& Fujisawa, 1978). PSBDOS reductase B could also be measured as the reduction of dichlorophenol-indophenol under similar conditions, with $50 \mathrm{nmol}$ of dichlorophenolindophenol instead of cytochrome $c$. The decrease in absorbance at $600 \mathrm{~nm}$ was measured and $\epsilon_{600}$ was taken as $21000 \mathrm{M}^{-1} \cdot \mathrm{cm}^{-1}$ (Yamaguchi \& Fujisawa, 1978).

\section{Growth of the organism and preparation of cell-free extracts}

C. testosteroni $\mathrm{T}-2$ was grown in minimal medium containing TS or PSB as sole carbon and energy source for growth (Locher et al., 1989). The organism was routinely inoculated $(1 \%, \mathrm{v} / \mathrm{v})$ into 1-litre portions of TS-minimal medium in 3-litre Erlenmeyer flasks and incubated for about $12 \mathrm{~h}$ on a rotary shaker $\left(130 \mathrm{rev} . / \mathrm{min}\right.$ at $30^{\circ} \mathrm{C}$ ): when the cell density reached an $A_{546}$ value of about 0.4 , sterile $0.3 \mathrm{M}$-PSB $(10 \mathrm{ml})$ was added, the $\mathrm{pH}$ was adjusted to about 7.0 with $2 \mathrm{ml}$ of sterile $5 \mathrm{M}-\mathrm{KOH}$, and the incubation was continued for 3-4 h. The bacteria were then harvested and stored at $-20^{\circ} \mathrm{C}$ as described previously (Thurnheer et al., 1986). This method yielded about $0.8 \mathrm{~g}$ wet wt./l of cells optimally induced for PSBDOS; cells in the stationary phase were practically inactive. Cells grown in PSBminimal medium were also active, but lower yields were obtained.

Pellets of frozen cells $(10 \mathrm{~g})$ were thawed and resuspended in $20 \mathrm{ml}$ of cold $20 \mathrm{~mm}$-potassium phosphate buffer, $\mathrm{pH} 6.8$, containing $1 \mathrm{~mm}$-dithiothreitol (buffer A). The cells were washed twice in the same volume of buffer $A$, and cell-free extracts were prepared by three passages through a chilled French pressure cell $(130 \mathrm{MPa})$ and subsequent centrifugation at $30000 \mathrm{~g}$ for $50 \mathrm{~min}$ at $4{ }^{\circ} \mathrm{C}$ (Thurnheer et al., 1986). The clear supernatant had a red-brown colour and was either used immediately for enzyme isolation or stored at $-20^{\circ} \mathrm{C}$. No loss of desulphonative activity was observed in extracts stored for several weeks at $-20^{\circ} \mathrm{C}$, but about $30 \%$ activity was lost in $24 \mathrm{~h}$ when stored at $4^{\circ} \mathrm{C}$.

\section{Purification of component $A$ and component $B$ of PSB dioxygenase}

F.p.l.c. was done with apparatus described elsewhere (Locher et al., 1989). All steps were carried out at $4{ }^{\circ} \mathrm{C}$, except that f.p.l.c. was done at room temperature, although fractions were collected on ice under a stream of $\mathrm{O}_{2}$-free $\mathrm{N}_{2}$. All solutions were thoroughly sparged with $\mathrm{O}_{2}$-free $\mathrm{N}_{2}$ or He. Considerable loss of activity occurred when sparging or dithiothreitol was omitted.

Step 1 : removal of nucleic acids with protamine sulphate. Crude extract (about $400 \mathrm{mg}$ of protein in $8-10 \mathrm{ml}$ ) was stirred gently under a constant stream of $\mathrm{O}_{2}$-free $\mathrm{N}_{2}$. Protamine sulphate $(3 \%$, $\mathrm{w} / \mathrm{v})$ in buffer $\mathbf{A}$ was added stepwise until a concentration of $0.3 \%(\mathrm{w} / \mathrm{v})$ was reached. The mixture was then stirred for $20 \mathrm{~min}$ and centrifuged at $30000 \mathrm{~g}$ for $30 \mathrm{~min}$ at $4{ }^{\circ} \mathrm{C}$. The pellet was discarded.

Step 2: f.p.l.c. anion-exchange chromatography. The Mono $Q$ column was equilibrated with buffer $A(5 \mathrm{ml} / \mathrm{min})$ and loaded with supernatant fluid from step 1. Proteins were eluted by an increasing gradient of $\mathrm{Na}_{2} \mathrm{SO}_{4}$ (Fig. 2). Fractions $(5 \mathrm{ml})$ were collected and tested for PSB dioxygenase activity. No single fraction was active, but red-brown fractions (entitled A) eluted at about $50 \mathrm{~mm}-\mathrm{Na}_{2} \mathrm{SO}_{4}$ (nos. 23-25) and yellow fractions (entitled B) eluted at about $100 \mathrm{~mm}-\mathrm{Na}_{2} \mathrm{SO}_{4}$ (nos. 31-35) were observed, and PSB dioxygenase activity was obtained when portions (50 $\mu \mathrm{l}$ each) of A and B were combined. Fractions containing significant activity were pooled separately to give the crude components A and B of the PSB dioxygenase system.

Step 3a : hydrophobic-interaction chromatography of component A. The phenyl-Superose column was equilibrated $(0.5 \mathrm{ml} / \mathrm{min})$ with buffer A containing $0.5 \mathrm{M}-\left(\mathrm{NH}_{4}\right)_{2} \mathrm{SO}_{4}$. Crude component A from step 2 was concentrated by membrane filtration (Centriprep) to about $3 \mathrm{ml}$, brought to $0.5 \mathrm{M}-\left(\mathrm{NH}_{4}\right)_{2} \mathrm{SO}_{4}$ by addition of $3 \mathrm{M}-\left(\mathrm{NH}_{4}\right)_{2} \mathrm{SO}_{4}$ and loaded on to the column, which was then rinsed for $10 \mathrm{~min}$. The concentration of $\left(\mathrm{NH}_{4}\right)_{2} \mathrm{SO}_{4}$ was decreased to $0.3 \mathrm{M}$ over $5 \mathrm{~min}$ and then to $0 \mathrm{M}$ over $20 \mathrm{~min}$, and $0.5 \mathrm{ml}$ fractions were collected. Portions $(50-100 \mu \mathrm{l})$ of the fractions was tested for PSB dioxygenase activity in the presence of component $\mathrm{B}$. Component $\mathrm{A}$ was eluted in a peak towards the end of the gradient [about $50 \mathrm{~mm}-\left(\mathrm{NH}_{4}\right)_{2} \mathrm{SO}_{4}$ ]. Fractions that were well separated from contaminative peaks were pooled.

Step 3b: hydrophobic-interaction chromatography of component B. The phenyl-Superose column was equilibrated $(0.5 \mathrm{ml} / \mathrm{min})$ with $20 \mathrm{~mm}$-potassium phosphate buffer, $\mathrm{pH} 7.5$, containing 


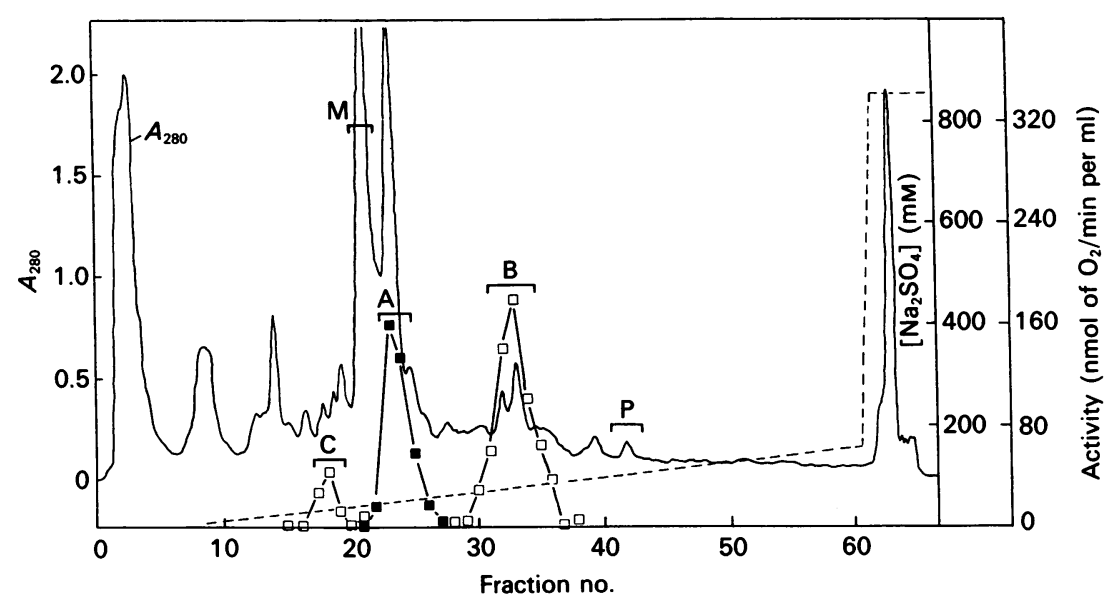

Fig. 2. Separation by anion-exchange chromatography of PSBDOS and other enzymes involved in TS degradation by $C$. testosteroni T-2

Protein ( $250 \mathrm{mg}$ ) was loaded on to a Mono Q column and eluted with a gradient of $\mathrm{Na}_{2} \mathrm{SO}_{4}(----)$. Component A (oxygenase; $\square$ ) of PSBDOS was located by the coupled assay with yellow fraction 33 of component B (reductase). Two activities $(\square)$ were located by the coupled assay with red-brown fraction 23 of component A, reductase B of PSBDOS and reductase C. Red component $M$ showed TS mono-oxygenase activity when combined with component B. The ring-cleaving enzyme (protocatechuate 4,5-dioxygenase) was located in fractions $39-45$ (P). Full experimental details are in the Experimental section.

$1 \mathrm{~mm}$-dithiothreitol (buffer B), which contained $0.5 \mathrm{M}$ $\left(\mathrm{NH}_{4}\right)_{2} \mathrm{SO}_{4}$. Crude component $\mathrm{B}$ from step 2 was brought to $0.5 \mathrm{M}-\left(\mathrm{NH}_{4}\right)_{2} \mathrm{SO}_{4}$ by addition of $3 \mathrm{M}-\left(\mathrm{NH}_{4}\right)_{2} \mathrm{SO}_{4}$ and the $\mathrm{pH}$ was adjusted to 7.5 with $5 \mathrm{M}-\mathrm{KOH}$. The sample was then concentrated to about $2 \mathrm{ml}$ and applied to the column, and $0.5 \mathrm{ml}$ fractions were collected. After $5 \mathrm{~min}$, the concentration of $\left(\mathrm{NH}_{4}\right)_{2} \mathrm{SO}_{4}$ was decreased to $0 \mathrm{M}$ over $30 \mathrm{~min}$. Yellow fractions, which exhibited cytochrome $c$ reductase activity and which showed PSB dioxygenase activity when combined with component $\mathrm{A}$, were eluted in a well-separated peak towards the end of the gradient [about $100 \mathrm{~mm}-\left(\mathrm{NH}_{4}\right)_{2} \mathrm{SO}_{4}$ ] and were pooled and concentrated.

Step 4a: gel-filtration chromatography of component $A$. Concentrated pooled fractions (about $3 \mathrm{ml}$ ) of component A from step 3a were applied to a gel-filtration column (G3000). Proteins were eluted in buffer A containing $100 \mathrm{~mm}-\mathrm{Na}_{2} \mathrm{SO}_{4}$. The flow rate was $3.0 \mathrm{ml} / \mathrm{min}$ and $1.5 \mathrm{ml}$ fractions were collected. PSB dioxygenase activity (assayed in the presence of component B) was eluted at about $25 \mathrm{~min}$ in a single symmetrical peak. The active slightly red fractions were concentrated 5-fold and either used directly for characterization or stored at $-20^{\circ} \mathrm{C}$.

Step 4b: gel-filtration chromatography of component $B$. Concentrated fractions of component $B$ from step $3 b$ were applied to the Superose column, which was equilibrated with buffer $\mathrm{B}$ containing $100 \mathrm{~mm}-\mathrm{Na}_{2} \mathrm{SO}_{4}$. The flow rate was $0.8 \mathrm{ml} / \mathrm{min}$ and $0.8 \mathrm{ml}$ fractions were collected. One protein peak only was eluted, at about $23 \mathrm{~min}$, and it contained reductase activity. Purified component $B$ was concentrated and stored at $-20^{\circ} \mathrm{C}$, or was used immediately.

\section{RESULTS}

\section{Purification of components A and B from PSBDOS}

Purification of PSBDOS from extract freed of nucleic acids was initiated by ion-exchange chromatography: attempts to fractionate with $\left(\mathrm{NH}_{4}\right)_{2} \mathrm{SO}_{4}$ led to extensive loss of activity. The choice of the stationary phase was important: Mono $Q$ gave high yields of active PSBDOS components whereas Toyo Soda DEAE columns gave low yields. The mobile phases contained $\mathrm{Na}_{2} \mathrm{SO}_{4}$, as appropriate, which did not inhibit PSBDOS; chloride salts gave diminished yields. Three oxygenases involved in the degradation of TS were detected in the eluate from Mono $Q$ column (Fig. 2), a putative two-component TS mono-oxygenase (reductase $\mathbf{B}$ and oxygenase $\mathrm{M}$ ), PSBDOS (reductases B and C, and oxygenase $\mathrm{A}$; see below) and the meta ring-cleavage reaction (protocatechuate 4,5-dioxygenase; $P$ ). Initial location of reductase $(B)$ and oxygenase (A and $M$ ) fractions was aided by their colour, yellow and red-brown respectively.

Activity of PSBDOS was routinely reconstituted by the mixture of fractions $B$ and A. Fraction C could replace fraction B in the dioxygenase assay, but as fraction $\mathrm{C}$ represented only about $15 \%$ of the total reductase activity, it has not been examined further. The active proteins, one each in fractions A and B, were purified to homogeneity. The purification described in the Experimental section has been done about six times, and typical results are given in Tables 1 and 2. Chromatography of each purified protein on the Superose gel-filtration column resulted in one single symmetrical peak (not shown). Each purified protein showed only one band on SDS/PAGE, whether stained by Coomassie Brilliant Blue (Fig. 3) or silver (not shown). PSBDOS thus belongs to a class of two-component dioxygenases with a homomultimeric (see below) oxygenase component.

Component B was identified as the reductase component of PSBDOS by its oxidoreductase activity with artificial electron acceptors; specific activities of 2.3, 1.4 and $5.3 \mathrm{~kat} / \mathrm{kg}$ of protein were observed with cytochrome $c$, dichlorophenol-indophenol and ferricyanide respectively. Component A showed no oxidoreductase activity with these substrates, but it could be reduced by both the reductase and $\mathrm{Na}_{2} \mathrm{~S}_{2} \mathrm{O}_{4}$ (see below), and it could oxygenate PSB when combined with component $\mathrm{B}$ and NADH. Component A was therefore considered as the oxygenase of PSBDOS.

Typically $10 \mathrm{~g}$ wet wt. of cells yielded $0.7 \mathrm{mg}$ of pure reductase B and $4 \mathrm{mg}$ of oxygenase $\mathrm{A}$. The yield could be doubled if only $90 \%$ purity was required. Purified and concentrated PSBDOS reductase $\mathrm{B}$ retained $80 \%$ of its activity for 3 days at $4{ }^{\circ} \mathrm{C}$ in buffer $\mathrm{B}$, whereas the oxygenase in buffer A lost about $60 \%$ under the same conditions. The f.p.l.c. procedure enabled purifications to be completed within $48 \mathrm{~h}$. Purified enzymes could be stored at $-20^{\circ} \mathrm{C}$ or $-70^{\circ} \mathrm{C}$ for at least 2 weeks in reduced buffers including $30 \%(\mathrm{v} / \mathrm{v})$ glycerol with negligible loss 
Table 1. Purification of PSBDOS oxygenase (component A)

The activity of PSBDOS oxygenase was measured as PSB-dependent $\mathrm{O}_{2}$-uptake rates in the presence of saturating amounts of partially purified reductase $B$ and corrected as appropriate for the presence of protocatechuate 4,5-dioxygenase, as described in the Experimental section.

\begin{tabular}{lcccccc}
\hline & $\begin{array}{c}\text { Total } \\
\text { Volume } \\
\text { (ml) }\end{array}$ & $\begin{array}{c}\text { Total } \\
\text { activity } \\
\text { (nkat) }\end{array}$ & $\begin{array}{c}\text { protein } \\
\text { (mg) }\end{array}$ & $\begin{array}{c}\text { Specific } \\
\text { activity } \\
\text { (mkat/kg } \\
\text { of protein) }\end{array}$ & $\begin{array}{c}\text { Yield } \\
(\%)\end{array}$ & $\begin{array}{c}\text { Purification } \\
\text { (fold) }\end{array}$ \\
\hline Crude extract & 8.5 & 570 & 415 & 1.36 & 100 & 1 \\
Protamine sulphate & 9.7 & 580 & 401 & 1.44 & 102 & 1.05 \\
Mono Q & 10.0 & 420 & 38 & 11.0 & 74 & 8.1 \\
Phenyl-Superose & 6.5 & 90 & 6.6 & 13.5 & 16 & 10.0 \\
TSK G3000 SW & 4.2 & 55 & 4.0 & $13.3^{*}$ & 9 & 9.8
\end{tabular}

* This value represents $800 \mathrm{nmol}$ of $\mathrm{O}_{2} / \mathrm{min}$ per $\mathrm{mg}$ of protein.

Table 2. Purification of PSBDOS reductase (component B)

Activity was measured as reduction of cytochrome $c$ as detailed in the text. Part of the losses seen in the Mono Q step is the removal of reductase $\mathrm{C}$, which was not purified (see the text).

\begin{tabular}{lcccccc}
\hline Solume & $\begin{array}{c}\text { Total } \\
\text { activity } \\
(\mu \text { kat) }\end{array}$ & $\begin{array}{c}\text { Total } \\
\text { protein } \\
(\mathrm{mg})\end{array}$ & $\begin{array}{c}\text { Specific } \\
\text { activity } \\
\text { (kat/kg } \\
\text { of protein) }\end{array}$ & $\begin{array}{c}\text { Yield } \\
(\%)\end{array}$ & $\begin{array}{c}\text { Purification } \\
\text { (fold) }\end{array}$ \\
\hline Crude extract & 8.5 & 7.5 & 415 & 0.018 & 100 & 1 \\
Protamine sulphate & 9.7 & 8.3 & 401 & 0.021 & 110 & 1.1 \\
Mono Q & 10.0 & 2.6 & 6.8 & 0.38 & 35 & 21.2 \\
Phenyl-Superose & 5.0 & 1.1 & 0.63 & 1.77 & 15 & 100 \\
Superose 12 & 2.0 & 0.97 & 0.52 & 1.87 & 13 & 104
\end{tabular}

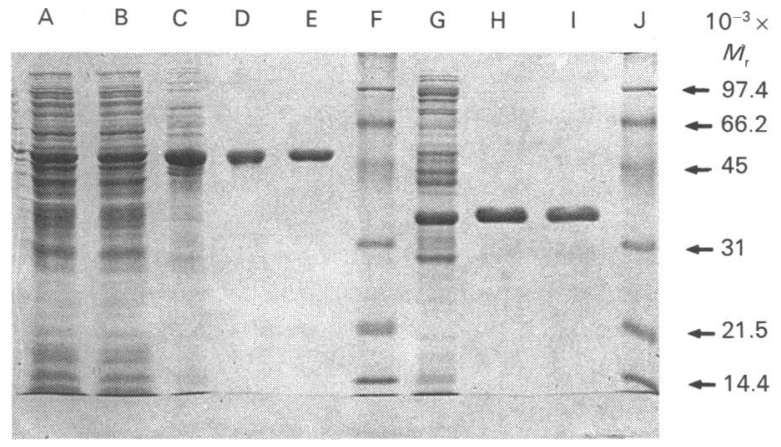

Fig. 3. SDS/PAGE of the purification of the two components of PSBDOS

Proteins were stained with Coomassie Brilliant Blue R250. Tracks : A, crude extract (18 $\mu \mathrm{g}$ of protein); B, crude extract treated with protamine sulphate $(16 \mu \mathrm{g}$ of protein); $\mathrm{C}$, pooled fractions of the oxygenase (component A) eluted from the Mono Q column ( $5 \mu \mathrm{g}$ of protein); D, pooled fractions of the oxygenase eluted from the phenyl-Superose column (1.5 $\mu \mathrm{g}$ of protein); E, pooled fractions of the oxygenase eluted from the TSK G3000 column $(1.5 \mu \mathrm{g}$ of protein); $\mathrm{F}$ and $\mathrm{J}$, standard protein markers (each about $0.5 \mu \mathrm{g}$ of protein); G, pooled fractions of reductase (component B) eluted from the Mono Q column (6 $\mu \mathrm{g}$ of protein); $\mathrm{H}$, pooled fractions of the reductase eluted from the phenyl-Superose column $(2 \mu \mathrm{g}$ of protein); I, pooled fractions of the reductase eluted from the Superose 12 column ( $2 \mu \mathrm{g}$ of protein).
Table 3. Amino acid composition of components A and B of PSBDOS

Cysteine was not determined separately, so the data represent minimum values. Tryptophan was not determined.

\begin{tabular}{lcc}
\hline & \multicolumn{2}{c}{$\begin{array}{c}\text { Amino acid composition } \\
\text { (residues/enzyme subunit) }\end{array}$} \\
\cline { 2 - 3 } Amino acid & $\begin{array}{c}\text { Component } \\
\text { A }\end{array}$ & $\begin{array}{c}\text { Component } \\
\text { B }\end{array}$ \\
\hline Asx & & \\
Glx & 30 & 12 \\
Ser & 40 & 32 \\
Gly & 27 & 20 \\
His & 38 & 31 \\
Arg & 8 & 11 \\
Thr & 27 & 13 \\
Ala & 15 & 16 \\
Pro & 42 & 50 \\
Tyr & 32 & 18 \\
Val & 9 & 3 \\
Met & 26 & 30 \\
Cys & 11 & 3 \\
Ile & 4 & 4 \\
Leu & 16 & 7 \\
Phe & 43 & 38 \\
Lys & 16 & 5 \\
Ins & 14 & 7
\end{tabular}




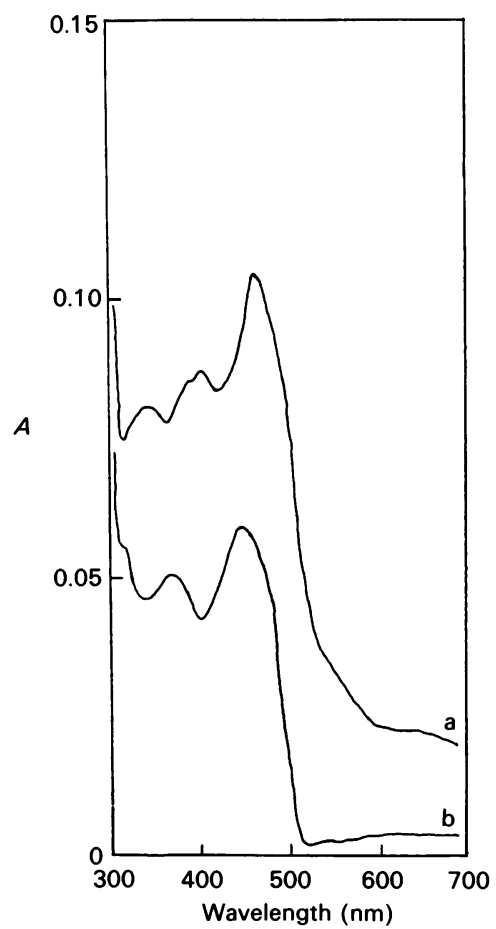

Fig. 4. Absorption spectrum of PSBDOS reductase and of the extracted flavin

a, Purified reductase $B(0.3 \mathrm{mg} / \mathrm{ml})$ in $20 \mathrm{~mm}$-potassium phosphate buffer, pH 7.5, containing $1 \mathrm{~mm}$-dithiothreitol. b, Supernatant fluid from the same sample after boiling and the removal of protein.

Table 4. Iron, inorganic sulphur and flavin contents of the components of PSBDOS

The values represent the means \pm S.D. for three to six determinations with two different enzyme preparations. $M_{\mathrm{r}}$ values of 36000 and 50000 respectively for the monomers of the reductase B and oxygenase of PSBDOS were used in calculations. Abbreviation: N.D., not determined.

Content $(\mathrm{mol} / \mathrm{mol}$ of enzyme monomer)

\begin{tabular}{lccc}
\cline { 2 - 4 } Enzyme & Iron & $\mathrm{S}^{2-}$ & Flavin (FMN) \\
\hline Reductase B & $1.9 \pm 0.1$ & $1.8 \pm 0.1$ & $0.85 \pm 0.1$ \\
Oxygenase A & $2.3 \pm 0.2$ & $1.6 \pm 0.2$ & 0 \\
Ferredoxin from & N.D. & $1.5 \pm 0.2$ & N.D. \\
S. platensis & & & \\
\hline
\end{tabular}

of activity; repeated freezing and thawing, however, led to a major loss of activity. The specific activity varied from preparation to preparation and can be as low as $60 \%$ of the value in Table 2, so we presume that some preparations contained inactive protein (cf. Fox et al., 1989).

\section{Determination of $\boldsymbol{M}_{\mathrm{r}}$, amino acid composition and $\boldsymbol{N}$-terminal amino acids}

The $M_{\mathrm{r}}$ values of the isolated PSBDOS proteins determined by SDS/PAGE were $36000 \pm 500$ for reductase B and $50000 \pm 1200$ for the oxygenase. Gel filtration resulted in $M_{\mathrm{r}}$ values of about 39000 (Superose) and 47000 (G2000) for native reductase B, and we presume the enzyme to be monomeric. Native dioxygenase

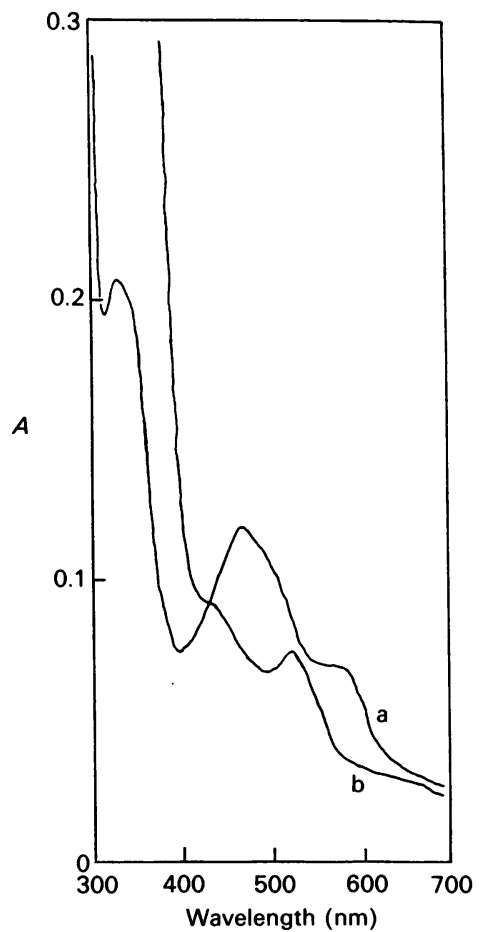

Fig. 5. Absorption spectra of PSBDOS oxygenase

a, Purified oxygenase $(1.2 \mathrm{mg} / \mathrm{ml})$ in $20 \mathrm{~mm}$-potassium phosphate buffer, $\mathrm{pH} 6.8$, containing $1 \mathrm{~mm}$-dithiothreitol. $\mathrm{b}$, The sample after reduction with $2 \mathrm{mM}-\mathrm{NADH}$ and catalytic amounts $(1 \mu \mathrm{g} / \mathrm{ml})$ of reductase $B$. The same spectrum was obtained by reducing with trace amounts of dithionite (not shown).

displayed $M_{\mathrm{r}}$ values of between 105000 (Superose) and 85000 (G2000), and we presume the enzyme to be homodimeric.

The $N$-terminal amino acid sequence determined for the oxygenase component was: Met-Leu-Thr-Ser-Glu-Asn-Asn-Gln-IleLeu-Thr-Arg-Val-Gly-Pro-Gly-Thr-Ala-Met-Gly-Xaa-LeuPhe-Arg-His-Phe-Xaa-Gln-Pro-Ala-Leu-Leu-Ser-Glu-Glu-. Identical sequences were obtained whether denatured samples from SDS/PAGE gels or proteins desalted by reverse-phase chromatography were analysed. These data confirm the homogeneity of the different preparations and support the homomultimeric structure of the oxygenase component. The $N$-terminal sequence of reductase B was: Xaa-(Lys)-Asp-XaaPro-(Val)-(Thr)-(Arg)-Ala-Ala-Val-Arg-Ala-Val-Ala-Arg-Asp(Val)-Leu-Ala-Leu-Glu-Xaa-Leu-His-Ala-Asn-Gly-Gln-Ala(where residues in parentheses have not been confirmed).

The amino acid composition of the components of PSBDOS is shown in Table 3.

\section{Flavin and [2Fe-2S] content}

PSBDOS reductase B was yellow ( $\lambda_{\text {max. }} 463 \mathrm{~nm}$; Fig. 4), which suggested a flavin cofactor. When the reductase was treated with acid or was boiled, protein was precipitated and the yellow colour remained in the supernatant fluid. The absorption spectrum of the extracted material (Fig. 4) was very similar to that of FMN, and this tentative identification was confirmed by co-chromatography with authentic material in two different h.p.l.c. methods and from the u.v.-absorption spectra of the separated material. The amount of FMN determined by the different methods in different preparations varied from 0.7 to $0.9 \mathrm{~mol} / \mathrm{mol}$ of protein. We presume there to be $1 \mathrm{~mol}$ of FMN/mol of reductase (Table 4). 
(a)

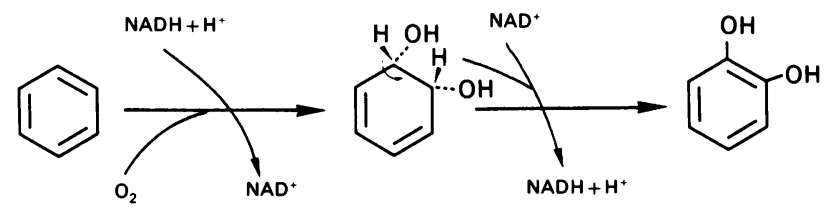

(b)

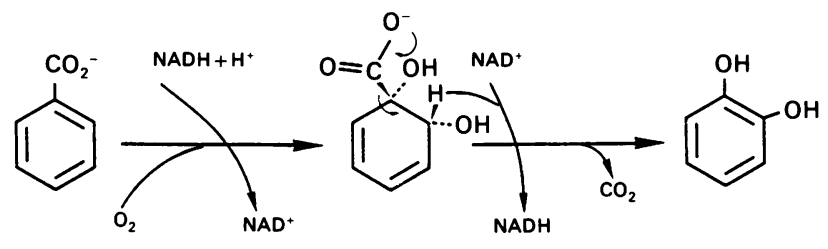

(c)

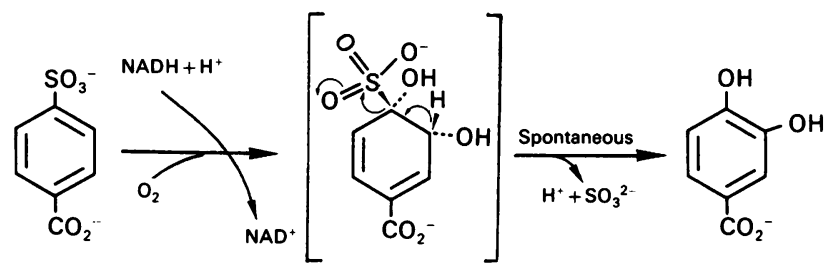

(d)<smiles>C[C@H](O)[C@H](O)[C@@H](C)[N+](=O)[O-]</smiles>

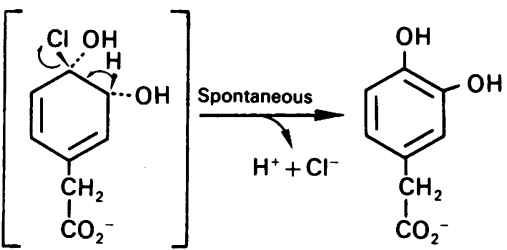

Scheme 2. Proposed reaction for the dihydroxylation and desulphonation of PSB by PSBDOS compared with reactions of other dioxygenases

Dihydroxylation of benzene $(a)$ or benzoate $(b)$ by the corresponding dioxygenase system leads to a stable dihydrodiol intermediate which is re-aromatized by the action of an $\mathrm{NAD}^{+}$-dependent dehydrogenase (Gibson \& Subramanian, 1984). In contrast $(c, d)$, dioxygenation and release of the $\mathrm{HSO}_{3}{ }^{-}$group from PSB (this work) or the $\mathrm{Cl}^{-}$group from 4-chlorophenylacetate (Markus et al., 1986) is achieved with the dioxygenase alone.

The difference between the u.v.-visible-absorption spectra of FMN and that of PSBDOS reductase (Fig. 4) and the electron transfer to, e.g., cytochrome $c$ suggested that the protein contained an iron-sulphur centre. Purified and desalted PSBDOS reductase $B$ contained $1.9 \mathrm{~mol}$ of iron and $1.8 \mathrm{~mol}$ of inorganic sulphur per mol of protein (Table 4). We obtained a value of $1.5 \mathrm{~mol}$ of $\mathrm{S}^{2-} / \mathrm{mol}$ for the ferredoxin from $S$. platensis, where $2 \mathrm{~mol}$ of $\mathrm{S}^{2-} / \mathrm{mol}$ is expected (Suhara et al., 1975). We presume the reductase $B$ to contain $1 \mathrm{~mol}$ of $[2 \mathrm{Fe}-2 \mathrm{~S}]$ per mol of protein, which presumably confers a ferredoxin function to the reductase.

The u.v.-visible-absorption spectrum of PSBDOS oxygenase showed maxima at 560, 467 and $327 \mathrm{~nm}$ in the oxidized state. In the reduced form, the spectrum of the oxygenase had maxima at 520 and $430 \mathrm{~nm}$ (Fig. 5). These characteristics are very similar to oxygenase components of other dihydroxylating oxygenases, especially that of the $o$-phthalate system $(560,466$ and $328 \mathrm{~nm}$, and 517 and $434 \mathrm{~nm}$; Batie et al., 1987), and they are ascribed to a Rieske iron-sulphur centre (Batie et al., 1987; Mason, 1988). Purified and desalted PSBDOS oxygenase contained $2.3 \mathrm{~mol}$ of iron and $1.6 \mathrm{~mol}$ of inorganic sulphur per mol of monomer (Table 4). Treatment with $10 \mathrm{~mm}$-EDTA and then desalting before analysis for iron resulted in no significantly lowered values of iron content. We thus presume PSBDOS oxygenase to contain one Rieske [2Fe-2S] centre per monomer. The activity of purified PSBDOS oxygenase was doubled when $\mathrm{Fe}^{2+}$ was added to the assay. This could be explained as replacement of weakly bound (mononuclear) iron that was lost during the purification, as is found by Batie et al. (1987). The fully active enzyme presumably contains (per monomer) one Rieske centre and at least one loosely bound iron atom.

\section{Substrate stoichiometry and substrate specificity}

Transformation kinetics of PSB by purified PSBDOS were monitored by h.p.l.c. and wet chemistry. PSB was degraded, and protocatechuate and sulphite were each found to accumulate in stoichiometric amounts. No dihydrodiol intermediate needed to be hypothesized and none was detected by different h.p.l.c. methods at neutral or acid $\mathrm{pH}$. Protocatechuate is therefore produced from PSB by the action of PSBDOS alone: no dehydrogenase or other enzyme reaction is required to re-aromatize any dihydrodiol.

Determinations of $\mathrm{O}_{2}$ uptake with limiting PSB or limiting NADH gave a $1: 1: 1$ stoichiometry for $\mathrm{PSB} / \mathrm{O}_{2} / \mathrm{NADH}$. When NADH was limiting, $0.9 \mathrm{~mol}$ of protocatechuate was found per mol of $\mathrm{NADH}$, indicating the 1:1 ratio also observed with PSB/protocatechuate.

We obtained apparent $K_{\mathrm{m}}$ values of 25-32 $\mu \mathrm{M}$ for PSB.

The substrate range of PSB dioxygenase was investigated by 
Table 5. Properties of known types of purified multi-component dioxygenases and of PSBDOS

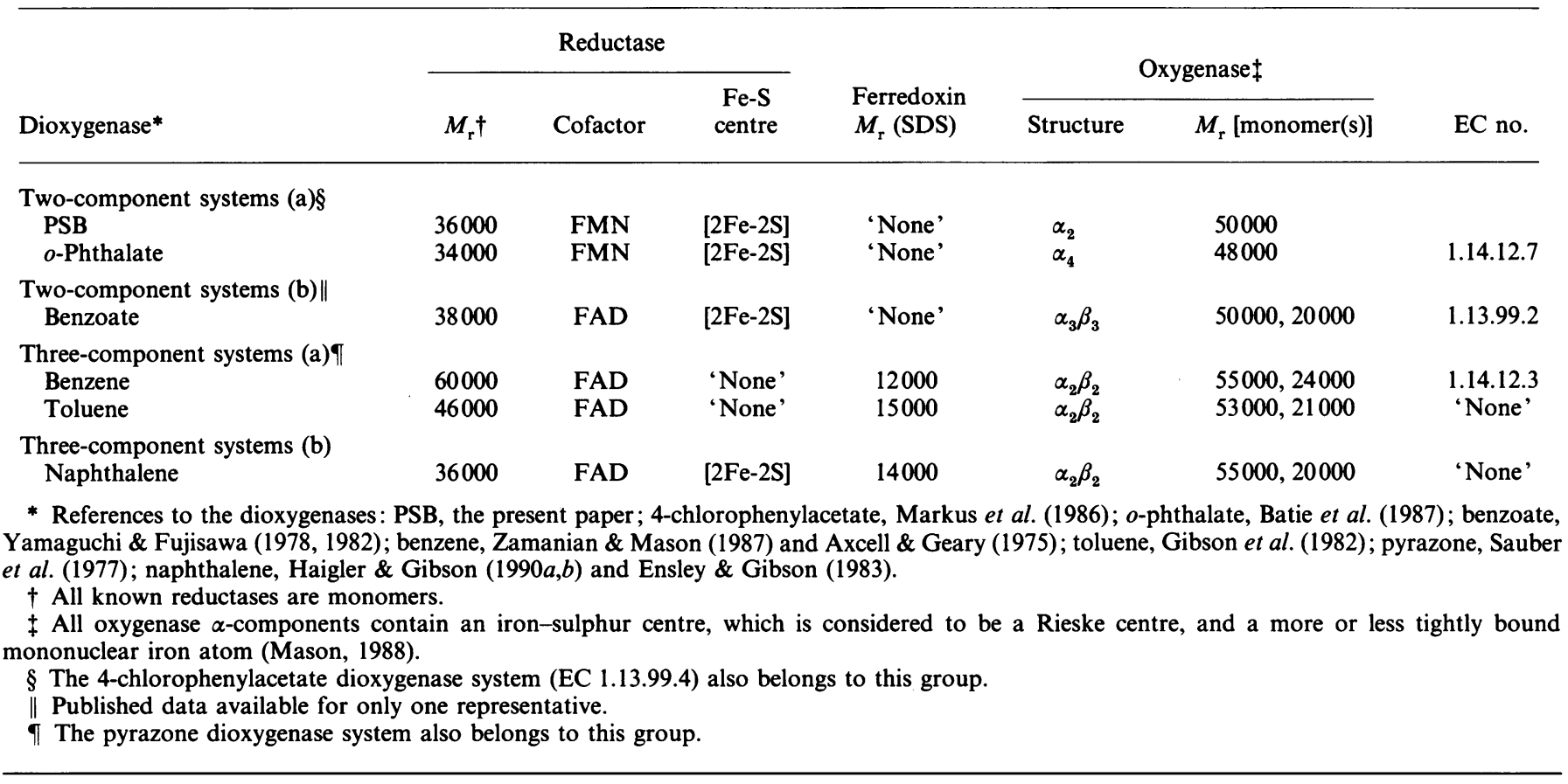

measuring substrate-dependent $\mathrm{O}_{2}$ uptake in the oxygen electrode. Eight sulphonated analogues (2- and 3-sulphobenzoate, unsubstituted benzenesulphonate and 4-methyl-, 4-hydroxy-, 4-amino-, 4-nitro- and 4-chloro-benzenesulphonate) and three homologues of PSB (4-sulphophenyl-acetate, -propionate and -butyrate) showed negligible activity. Most carboxy analogues of PSB (benzoate and 4-methyl-, 4-hydroxy-, 4-amino-, 4-nitroand 4-chloro-benzoate) were not substrates, but an effect was observed with terephthalate ( $\leqslant 10 \%$ of the rate with PSB). This reaction was not linear, came to a stop after about $1 \mathrm{~min}$ and was not restarted by the addition of more terephthalate, though the enzyme was shown to be fully active on added PSB. Only slight substrate disappearance and no formation of product were observed by h.p.l.c. We do not understand this effect.

\section{DISCUSSION}

Growing cells of strain T-2 are calculated to have a specific activity of $2.6 \mathrm{mkat} / \mathrm{kg}$ of protein for the desulphonation of PSB (Locher et al., 1989), whereas we observe $1.4 \mathrm{mkat} / \mathrm{kg}$ of protein in crude extracts: it therefore seems reasonable that we have isolated proteins responsible for the reaction observed in vivo. PSBDOS reductase B seems to represent about $1 \%$ of soluble cell protein, assuming no significant loss of activity on cell rupture and on 100-fold purification of the higher-activity reductase. By a similar calculation, PSBDOS oxygenase represents about $10 \%$ of soluble cell protein. This value is roughly consistent with the band of oxygenase protein in SDS/PAGE of crude extract (Fig. 3). The molarity of the reductase in the cell would then be 0.3 relative to 1.0 for the dimeric oxygenase. The specific activity of reductase B is some 100 -fold higher with the artificial electron acceptors than the complete PSBDOS with excess reductase (1.9 versus $0.01 \mathrm{~kat} / \mathrm{kg}$ of protein; Tables 1 and 2). There is, however, a paradox in these numbers: if the specific activity of the reductase really is so high, why is an excess required to assay the oxygenase component? A better understanding of the interaction between reductase and oxygenase is required. It is currently difficult to understand how the reductase can supply enough reducing power for the two oxygenases it serves. Perhaps we have a poor extractive technique for reductase B, and still worse for reductase C (Fig. 2), which could be genetically the reductase corresponding to the dioxygenase. However this question is resolved, we now have an assay system that allows the activity of an oxygenase to be directly correlated to the amount of protein in the assay. This contrasts with the situation in Alcaligenes sp. strain O-1, in which the specific activity seems to be a function of protein concentration (Thurnheer et al., 1990; cf. Gibson et al., 1982), and will in future allow direct comparisons of different preparations and different oxygenases.

The typical bacterial degradative pathway for an aromatic hydrocarbon (e.g. benzene or benzoate; Schemes $2 a$ and $2 b$ ) involves dioxygenation by a multi-component dioxygenase, which yields a stable dihydrodiol. The dihydrodiol is rearomatized by a movement of electrons that leads to the formal release of a hydride ion, a poor leaving group, whose efficient removal requires an $\mathrm{NAD}^{+}$-linked dehydrogenase (Gibson \& Subramanian, 1984). The conversion of PSB into protocatechuate, in contrast, requires no dehydrogenase, or any enzyme, in addition to PSBDOS, and no intermediate was detected. The hypothetical sulphono-dihydrodiol intermediate (Scheme 2c) represents the sulphite addition complex of a ketone, a highly unstable configuration that will spontaneously lose the good leaving group, sulphite, with the concomitant energetically favourable re-aromatization. The direction of the formal electron flow for desulphonation reverses that required for, e.g., the decarboxylation of the analogous benzoate dihydrodiol (Schemes $2 b$ and $2 c$ ). It is unclear whether desulphonation occurs at the enzyme surface or shortly after the intermediate has left the enzyme, but the unstable nature of this hypothetical intermediate makes it likely that the reaction occurs at the enzyme surface. This mechanism confirms a suggestion made by Brilon et al. (1981). An analogous situation is seen with 4-chlorophenylacetate 3,4-dioxygenase (Scheme 2d; Markus et al., 1986), and possibly serves as a model for the newly observed oxygenases, which precede ring cleavage of neighbouring heterocycles at the bridge heteroatom (Fortnagel et al., 1990; van Afferden et al., 1990).

One desulphonative reaction has been characterized 
previously. Sulphonoacetaldehyde, derived from taurine (2-aminoethane sulphonate) by transamination, is subject to hydrolysis to yield sulphite and acetate (EC 4.4.1.12; Kondo \& Ishimoto, 1972; Shimamoto \& Berk, 1979, 1980). This intermediate, with a $\mathrm{C}-\mathrm{S}$ bond labilized by the adjacent aldehyde group, has no similarity to the stable $\mathrm{C}-\mathrm{S}$ bond on an aromatic ring. A closer analogy is the desulphonation of linear alkanesulphonates in cell extracts (Thysse \& Wanders, 1974): no ${ }^{18} \mathrm{O}_{2}$ experiments were done, but an oxygenase reaction was apparently necessary to labilize the $\mathrm{C}-\mathrm{S}$ bond and yield the unstable sulphite addition complex of an aldehyde. Endo et al. (1977) and Kondo et al. (1982) indicated a multi-component desulphonative system involving $\mathrm{NADH}$ and $\mathrm{O}_{2}$ for benzene sulphonate, but had activities that were presumably too low (about $10 \mu \mathrm{kat} / \mathrm{kg}$ of protein) to permit further work. A. M. Cook \& C. Joannou (unpublished work) have preliminary evidence for a two-component orthanilate dioxygenase system in Alcaligenes sp. strain O-1 (cf. Thurnheer et al., 1990). In contrast, Feigel \& Knackmuss (1990) presented evidence for a different type of desulphonation, namely after ring cleavage, analogous to several dechlorinations (Reineke \& Knackmuss, 1988).

The amino acid compositions (Table 3 ) of the oxygenase and reductase components of PSBDOS are similar to those of other systems (e.g. Axcell \& Geary, 1975; Markus et al., 1986; Batie et al., 1987), but no significant similarity of the $N$-termini to published sequences was detected using the Genetics Computer Group program package (University of Wisconsin, Madison, WI, U.S.A.). The only direct comparison undertaken (at the level of cell extracts), with all four proteins of the benzene dioxygenase system, showed no cross-reaction on Western blotting (C. Joannou \& J. R. Mason, personal communication ; cf. Zamanian \& Mason, 1987). The high content of apolar amino acids of both components of PSBDOS (about $47 \%$ for the oxygenase and about $49 \%$ for the reductase) is in agreement with the hydrophobic behaviour of the proteins on hydrophobic-interaction chromatography. The high specificity of PSB dioxygenase, if typical of desulphonative systems, might explain narrow substrate ranges observed in bacteria utilizing sulphonates as carbon and energy sources (cf. Thurnheer et al., 1986). Dioxygenases with apolar substrates are reported to have broad substrate ranges (Zamanian \& Mason, 1987). PSBDOS displays a high affinity for PSB (about $30 \mu \mathrm{M}$ ). There would appear to be no corresponding data for other dioxygenases.

PSBDOS, with its reductase coupled directly to a homodimeric oxygenase, is the simplest multi-component dioxygenase yet described (Table 5). Together with the $o$-phthalate dioxygenase system (Batie et al., 1987) it obviously belongs to a group of enzyme systems with FMN-containing reductases, which harbour a ferredoxin function, and with homomultimeric oxygenases. Three other classes of multi-component dioxygenases are also defined (Table 5). The nomenclature of these systems, in contrast, is ill-defined. Only four are mentioned in EC lists, two of them are provisional, and none of them conforms fully with EC recommendations. Given the present sub- and sub-sub groups in EC 1., we suggest that these systems (Table 5) all belong to EC 1.14.12.-. Correspondingly, PSBDOS has the trivial name '4-sulphobenzoate 3,4-dioxygenase system' and the systematic name '4-sulphobenzoate,NADH: oxygen oxidoreductase $(3,4-$ hydroxylating, sulphite-forming)'. The 'comments' must then be used to define the system: 'iron-sulphur-flavoprotein (FMN) reductase; no independent ferredoxin; homomultimeric iron-sulphur oxygenase: requires added iron'. In this way, both the known systems and simple variants thereof can be described. The genes encoding the protein components of known dioxygenative systems, where known, are located on operons (Zylstra \& Gibson, 1989), which accentuates the functional interrelatedness of the components, and lends weight to their classification as systems.

We are grateful to Dr. J. R. Mason and Dr. C. Joannou, King's College, London for advice, discussions and Western blots. We thank Dr. T. Vorherr, Institute of Biochemistry, ETH-Zürich, for determining $N$-termini and amino acid compositions, Mr. C. Henehan, University of Zürich, for measuring iron by atomic absorption spectroscopy, and Dr. A. Marcomini, University of Venice, for the gift of PSB homologues. This work was supported by a grant from the Kommission zur Förderung der wissenschaftlichen Forschung (Project 1567).

\section{REFERENCES}

Axcell, B. C. \& Geary, P. J. (1975) Biochem. J. 146, 173-183

Batie, C. J., LaHaie, E. \& Ballou, D. P. (1987) J. Biol. Chem. 262, 1510-1518

Beinert, H. (1983) Anal. Biochem. 131, 373-378

Bradford, M. (1976) Anal. Biochem. 72, 248-254

Brilon, C., Beckmann, W. \& Knackmuss, H.-J. (1981) Appl. Environ. Microbiol. 42, 44-55

Buder, R. \& Fuchs, G. (1989) Eur. J. Biochem. 185, 629-635

Cain, R. B. (1981) in Microbial Degradation of Xenobiotics and Recalcitrant Compounds (Leisinger, T., Cook, A. M., Hütter, R. \& Nüesch, J., eds.), pp. 325-370, Academic Press, London and New York

Cain, R. B. \& Farr, D. R. (1968) Biochem. J. 106, 859-877

Endo, K., Kondo, H. \& Ishimoto, M. (1977) J. Biochem. (Tokyo) 2, 1397-1402

Ensley, B. D. \& Gibson, D. T. (1983) J. Bacteriol 155, 505-511

Ensley, B. D., Gibson, D. T. \& Laborde, A. L. (1982) J. Bacteriol. 149, 948-954

Feigel, B. J. \& Knackmuss, H.-J. (1990) Forum Mikrobiol. 13, 75

Fortnagel, P., Harms, H., Wittich, R.-M., Krohn, S., Meyer, H., Sinnwell, V., Wilkes, H. \& Francke, W. (1990) Appl. Environ. Microbiol. 56, 1146-1156

Fox, B. G., Froland, W. A., Dege, J. E. \& Lipscomb, J. D. (1989) J. Biol. Chem. 264, 10023-10033

Gibson, D. T. \& Subramanian, V. (1984) in Microbial Degradation of Organic Compounds (Gibson, D. T., ed.), pp. 181-252, Marcel Dekker, New York

Gibson, D. T., Yeh, W., Liu, T. \& Subramanian, V. (1982) in Oxygenases and Oxygen Metabolism (Nozaki, M., Yamamoto, S., Ishimura, Y., Coon, M. J., Ernster, L. \& Estabrook, W., eds.), pp. 51-61, Academic Press, New York

Haigler, B. E. \& Gibson, D. T. (1990a) J. Bacteriol. 172, 457-464

Haigler, B. E. \& Gibson, D. T. (1990b) J. Bacteriol. 172, 465-468

Halwachs, W. (1978) Biotechnol. Bioeng. 20, 281-285

Kondo, H. \& Ishimoto, M. (1972) J. Biochem. (Tokyo) 72, 487-489

Kondo, H., Yazawa, M., Enami, H. \& Ishimoto, M. (1982) Sulphur Amino Acids 5, 237-242

Laemmli, U. K. (1970) Nature (London) 227, 680-685

Locher, H. H., Leisinger, T. \& Cook, A. M. (1989) J. Gen. Microbiol. 135, 1969-1978

Lowry, O. H., Rosebrough, N. J., Farr, A. L. \& Randall, R. J. (1951) J. Biol. Chem. 193, 265-275

Markus, A., Krekel, D. \& Lingens, F. (1986) J. Biol. Chem. 261, 12883-12888

Mason, J. R. (1988) Int. Ind. Biotechnol. 8, 19-24

Merril, C., Goldmann, D. \& van Kenren, M. L. (1983) Methods Enzymol. 96, 230-239

Reineke, W. \& Knackmuss, H.-J. (1988) Annu. Rev. Microbiol. 42, 263-287

Sauber, K., Fröhner, C., Rosenberg, G., Eberspächer, J. \& Lingens, F. (1977) Eur. J. Biochem. 74, 89-97

Scholtz, R., Leisinger, T., Suter, F. \& Cook, A. M. (1987) J. Bacteriol. 169, 5016-5021

Shimamoto, G. \& Berk, R. S. (1979) Biochim. Biophys. Acta 569, 287-292

Shimamoto, G. \& Berk, R. S. (1980) Biochim. Biophys. Acta 632, $121-130$

Suhara, K., Takemori, S., Katagiri, M., Wada, K., Kobayashi, H. \& Matsubara, H. (1975) Anal. Biochem. 68, 632-636 
Swisher, R. D. (1987) Surfactant Biodegradation, 2nd edn., pp. 517-645, Marcel Dekker, New York

Thurnheer, T., Köhler, T., Cook, A. M. \& Leisinger, T. (1986) J. Gen. Microbiol. 132, 1215-1220

Thurnheer, T., Zürrer, D., Höglinger, O., Leisinger, T. \& Cook, A. M. (1990) Biodegradation 1, 55-64

Thysse, G. J. E. \& Wanders, T. A. (1974) Antonie van Leeuwenhoek 40, 25-37

Received 10 August 1990/1 October 1990; accepted 9 October 1990 van Afferden, M., Schacht, S., Klein, J. \& Trüper, H. G. (1990) Arch. Microbiol. 153, 324-328

Yamaguchi, M. \& Fujisawa, H. (1978) J. Biol. Chem. 253, 8848-8853

Yamaguchi, M. \& Fujisawa, H. (1982) J. Biol. Chem. 257, 12497-12502

Zamanian, M. \& Mason, J. R. (1987) Biochem. J. 244, 611-616

Zürrer, D., Cook, A. M. \& Leisinger, T. (1987) Appl. Environ. Microbiol. 53, 1459-1463

Zylstra, G. J. \& Gibson, D. T. (1989) J. Biol. Chem. 264, 14940-14946 